\title{
Realistic Mathematics Education Based on Virtual Network in Increasing the Understanding of Geometry Concept
}

\author{
Octarina Hidayatus Sholikhah ${ }^{1 *}$, Rasmita ${ }^{2}$ \\ 1 Universitas PGRI Madiun, Indonesia \\ ${ }^{2}$ Universitas Putra Indonesia YPTK Padang, Indonesia
}

Corresponding Author: Octarina Hidayatus Sholikhah, octariana@unipma.ac.id*

\section{ABSTRACT}

This article was to improve the understanding of elementary school students' geometry concepts through the Realistic Mathematic Education (RME) model that assisted by virtual nets. This research was classroom action research. This research was conducted in two cycles where each

ARTICLE INFO

Article history:

Received

March 05, 2020

Revised

May 03, 2020

Accepted

June 07, 2020 cycle had two meetings. The research subjects were the fifth grade students. In this study two cycles were carried out where if the first cycle had not yet reached the specified indicators. It would be improved in the next cycle or the second cycle. Data collection techniques used tests and observations in each cycle. In the second cycle it was felt that the target had been reached, so that the study would end until the second cycle. At the pre-cycle stage obtained a classical percentage of $50 \%$, the first cycle obtained a percentage of $70 \%$ and in the second cycle increased by $100 \%$. Thus the researcher concludes that through the RME model assisted by virtual nets can improve the understanding of geometrical concepts of elementary school students.

Keywords: Virtual Network, Realistic Mathematics Education, Geometry Concept

How to cite

Sholikhah, O., Rasmita, R. (2020). Realistic Mathematics Education Based on Virtual Network in Increasing the Understanding of Geometry Concept. Jurnal Iqra' : Kajian Ilmu Pendidikan, 5(1). 85-93. https://doi.org/10.25217/ji.v5i1.785

Journal Homepage http://journal.iaimnumetrolampung.ac.id/index.php/ji/

This is an open access article under the CC BY SA license https:/ / creativecommons.org/licenses/by-sa/4.0/

Published by

\section{INTRODUCTION}

One of the abilities that professional educators must possess is being able to make students comfortable and at ease when carrying out learning both inside and outside the classroom. Professional teachers believe that they support, approve and carry out activities according to the stated educational goals (Skaalvik \& Skaalvik, 2007). The high level of confidence of the teacher has been shown to have many positive impacts including in increasing student motivation and achievement in the classroom. Thus the teacher is expected to be able to work for more difficult challenges from time to time (Paneque \& Barbetta, 2006). With the rapid changes that occur in the world of education, teachers are required to be able to adjust to ways that are more creative, flexible and practical, especially in learning (Arslan \& Yavuz, 2012). Some findings stated that teachers must teach according to appropriate learning strategies (Scheerens, 2015; Van de Grift, W. J. C. M., Van der Wal, M., \& Torenbeek, 
2011), creating an orderly and safe learning environment (Panayiotou et al., 2014; Seidel \& Shavelson, 2007), provide opportunities for students to learn more deeply, not discriminating students with each other (Kyriakides et al., 2002; Van de Grift, W. J. C. M., Van der Wal, M., \& Torenbeek, 2011), convey high expectations to students if later successfully solve a problem (Stronge et al., 2011), and provide positive feedback to students (Harbour et al., 2015; Kyriakides et al., 2002). Not only teaches about learning and material in the classroom, educators also teach students about character building and skills to become the nation's successors who can be proud of in the future (Ekayani, 2017). Professional educators are those who have competent and mastered in the field and teaching materials and are able to choose learning methods well so that the learning process can run well (Falahudin, 2014; Marzuki \& Khanifah, 2016).

Mathematics education is one of education which has an important role in daily life and geometry is a branch of mathematics. In all educational curricula call for mandatory geometry to be studied by all students at all levels of education (National Council of Teachers of Mathematics, 2000). Many studies show that many students have difficulty in learning geometry and show poor learning outcomes in mathematics classes. In learning at State of Elementary School (SDN) 02 Taman Kota Madiun, many teachers did not understand the role and use of approaches and models in learning activities. Many teachers were still guided by conventional learning which makes students bored and does not understand the learning material well. Moreover, in the material of cube and beam nets in grade 5, students will be difficult if they only refer to the textbooks and explanations from the teacher, but do not use media that can make students better understand the material being taught.

Those problems caused students did not understand the mathematics material that has been taught, especially in the material webs of blocks and cubes. Because teachers ddi not focus on the lessons taught and cannot really understand how the shapes and types of cube and beam webs. It has led to misunderstandings between teachers and students regarding learning material. The effect of the Realistic Matematic Education (RME) approach on students can improve the learning process and understanding of mathematical geometry concepts in students with a pretty good value acquisition than before (Hayes et al., 2017). Mathematics learning using RME approach with the subject matter of cubes and blocks can improve understanding and understanding of students' geometric concepts (Muncarno \& Astuti, 2018). Certainly not only using the RME approach can improve students' understanding of geometrical concepts, but also using media that can help students to better understand material about cube and beam webs. Didactic Design Media on material cube and beam webs can improve students 'understanding of geometric concepts in developing students' critical thinking skills (Lestari et al., 2018). The use of threedimensional media in learning to build cubes and beams can improve students' understanding of geometrical concepts (Hunt et al., 2011). The media used must 
be made as interesting as possible and as clear as possible so that students can understand the message of the media.

Previous research, most of the use of media networks of cubes and blocks are still in concrete form so that teachers need to lift the media when moving class. Actually it has a good effect but it is not efficient in placement (Susilawati, 2019). Hikmah also applied concrete webs and concrete blocks to improve the ability to solve problems, but the problem referred to was only in problems that had formed mathematical equations (Hikmah, 2018). Another thing, in his research Zakiy developed learning media in the form of android on cube and beam webs. The results stated that the android media is suitable for use in learning but has not been further tested whether it can improve understanding of the concept of material (Zakiy et al., 2018).

Different from the present research that used the Realistic Matematic Education (RME) approach in order to facilitate the learning of mathematics, of course, in determining networks of cubes and beams. RME itself is a learning method that teaches students material using real or real problems in their lives. students are given contextual problems, or problems related to realistic situations. RME learning is the use of reality and the environment that is understood to improve understanding of the concept of geometry to be better than before (Ningsih, 2014). In addition to using an approach, media in learning is also needed to more easily distribute material to students and students more easily understand it. The purposes of this study was to improve the understanding of elementary school students' geometry concepts through the RME model assisted by virtual nets.

\section{METHODS}

This research used Classroom Action Research which was focused on classroom situations, or Classroom Action Research (Scanlon, 2018). This class action research conducted in a participatory collaborative manner, namely research by collaborating collaboratively with teachers and researchers. The process of action taken in this study was strived so that the problems that occur can be resolved, as well as to improve the quality of learning.

The subjects of this study were fifth grade students of elementary schools. The object of this class action research was the application of the Realistic Matematic Education (RME) approach to mathematics subjects to improve understanding of geometry concepts. This research was carried out with four stages, namely planning, implementation, observation, and reflection. In this study, the data collection methods used are; (1) observation method; (2) test method; and (3) documentation method.

The data obtained from research through data collection methods, then processed with descriptive analysis to illustrate the state of increasing achievement indicators of success in each cycle and to describe the success of learning mathematics subjects. The data in the form of numbers were processed quantitatively and presented in the form of numbers. The instrument used in this study was in accordance with the method of data collection, for the 
researcher observation method using the observation sheet, and for the test method the researcher used the questions.

\section{RESULT AND DISCUSSION Pre Cycle Results}

In this activity the researchers identified student learning outcomes data obtained from class teachers so that researchers know students' mathematical understanding before being given action. Learning outcomes data was known if not all students in the class meet the minimum passing score. There are still $50 \%$ of students who have not achieved that grade.

\section{Cycle 1 results}

Based on observations in the implementation of cycle 1, the activeness of the teacher has reached $93.75 \%$ which included in the active criteria and has reached the expected indicator of $80 \%$, but the percentage of students who reach the minimum passing grade is $70 \%$ students and this fact cannot be said achieved the expected achievement indicator of $80 \%$. After further investigation, the constraints of students in Cycle I were that students could associate mathematics learning with real life and thoughts but it was still a little difficult to understand the virtual web media properly. Although there were also many students who understand the media and the approach adopted by the teacher, there are still students who do not dare to ask the teacher even though they have been given the opportunity to ask questions by the teacher. This is certainly a problem of students in terms of learning so as to make students get learning outcomes that are not optimal. Based on these constraints, research must proceed to cycle 2 with an improvement plan where students will be rewarded if they are enthusiastic and active during the teaching and learning process.

\section{Cycle 2 results}

Based on observations in the implementation of cycle 2, the teacher's activeness has reached $100 \%$ which is included in the active criteria and has reached the expected indicator that is $80 \%$ and the percentage of students who reach the minimum passing grade is $100 \%$ so that it has reached the expected achievement indicator of $80 \%$. Thus the constraints of students in cycle I have been successfully corrected well in cycle II and get very satisfying results. The study stopped because all the indicators of achievement have been met. In summary, the following is a comparison of results from pres cycle, cycle 1 , and cycle 2. 
Tabel 1. The Resulf of Pre Cycle, Cycle I and Cycle II

\begin{tabular}{|l|c|c|c|}
\hline \multicolumn{1}{|c|}{ Aspect } & Pre Cycle & Cycle I & Cycle II \\
\hline Max value & 85 & 90 & 100 \\
\hline Min Value & 50 & 65 & 75 \\
\hline Average Value & 67,5 & 78,5 & 92,6 \\
\hline Percentage of completeness & $50 \%$ & $70 \%$ & $10 \%$ \\
\hline
\end{tabular}

The findings showed that the virtual nets media based on the Realistic Matematic Education (RME) approach in the mathematics subject matter of cube and beam space nets can improve the understanding of elementary school students' geometric concepts. This is based on (1) an increasing in student learning outcomes, especially in the material cube nets and beams; (2) the number of students who have scores exceeding the minimum grade of mathematics passing standards was more than $80 \%$; (3) teachers and students were more interested in the learning process because learning media were packaged in digital form.

The alignment of this research with some previous studies was to produce conclusions stating that if the application of Realistic Matematic Education (RME) in the learning process can produce outputs that benefit teachers, students, and schools which will result in better education processes. In his research, Rahman concluded that in two cycles it turned out that Realistic Matematic Education (RME) was able to make teachers and students collaborate actively in the class so that the learning conditions were more conducive. It was evidenced by the learning outcomes of students experiencing completeness with an average grade above the minimum grade passing grade (Rahman, 2017).

Other research stated that the effect of applying RME can improve students' mathematical reasoning abilities higher than other learning models (Rindi Antika, 2019). Different from the finding implied that RME is a model that emphasizes contextual problems in daily life so that indirectly RME is also able to improve students' ability to solve problems if applied correctly (Bonotto, 2008; Fatimah et al., 2020; Fauzan, 2002). Students are able to find their own answers to problems from real life, and students can develop and practice their knowledge by discussing the results of their answers with peers (Arrahim \& Widayanti, 2018; Arsaythamby \& Zubainur, 2014; Fauzan et al., 2002). Another positive impact of RME is that it can improve students' mathematical selfconcepts in the millennial era. Mathematical self-concept of students is based on observations that state students become more enthusiastic in carrying out mathematical learning activities and active in learning activities (Sitorus \& Masrayati, 2016; Sopyan et al., 2019). 


\section{CONCLUSIONS}

This study concludes that through the virtual nets media based on the Realistic Matematic Education (RME) in the mathematics subject matter the cube and beam space nets can improve the understanding of the geometrical concepts of fifth grade students of State of Elementary School (SDN) 02 Taman Kota Madiun. The implications of this research can be applied in the scientific and practical world. In the scientific world, this can be used as a reference in developing RME. For practical domain RME can be used as an effort to improve students' reasoning abilities. This research also shows that RME can be applied to have a better impact on the quality of learning in the classroom as well as the need for further development of this research. In the end, RME is very important to be applied in mathematics learning especially for elementary school students who are still in the stage of thinking concretely.

\section{ACKNOWLEDGEMENTS}

The authors were sincere appreciation to The Rector of Universitas PGRI Madiun. The authors wish to thank to participant, teacher, and school were support for this research. Acknowledgments were also extended to all who contributed to this research.

\section{AUTHOR CONTRIBUTION STATEMENTS}

Octarina Hidayatus Sholikhah (OHS) is lecturer at Department of Primary Education Universitas PGRI Madiun. OHS is the editor of Premiere Educadum: Jurnal Pendidikan Dasar dan Pembelajaran. OHS was the main author in this paper. Rasmita $(\mathrm{R})$ was the second author who provided support in being a comparative researcher.

\section{REFERENCES}

Arrahim, \& Widayanti, N. (2018). Perbandingan Pemahaman Konsep Siswa Kelas Iv Dengan Menggunakan Model Problem Based Learning (Pbl) Dan Model Realistik Mathematic Education (Rme) Pada Mata Pelajaran Matematika Di Sdit Darul Hasani Kabupaten Bekasi. Pedagogik, VI(2), 134-143. Google Scholar

Arsaythamby, V., \& Zubainur, C. M. (2014). How a Realistic Mathematics Educational Approach Affect Students' Activities in Primary Schools? Procedia - Social and Behavioral Sciences, 159, 309-313. https://doi.org/10.1016/j.sbspro.2014.12.378

Arslan, C., \& Yavuz, G. (2012). A Study on Mathematical Literacy Self-Efficacy Beliefs of Prospective Teachers. Procedia - Social and Behavioral Sciences, 46, 5622-5625. https:// doi.org/10.1016/j.sbspro.2012.06.484 
Bonotto, C. (2008). Realistic Mathematical Modeling and Problem Posing. Dalam Modelling and Applications in Mathematics Education (In W. Blum, hlm. 185-192). Spinger. https:/ / doi.org/10.1007/978-1-4419-0561-1

Ekayani, P. (2017). Pentingnya penggunaan media pembelajaran untuk meningkatkan prestasi belajar siswa. Jurnal Fakultas Ilmu Pendidikan Universitas Pendidikan Ganesha Singaraja, 2(1), 1-11. Google Scholar

Falahudin, I. (2014). Pemanfaatan media dalam pembelajaran. Jurnal Lingkar Widyaiswara, 1(4), 104-117. Google Scholar

Fatimah, Siregar, E. Y., \& Ahmad, M. (2020). efektivitas penerapan pendidikan matematika realistik terhadap kemampuan pemecahan masalah matematis siswa smk negeri 1 batang angkola. jurnal MathEdu (Mathematic Education Journal), 3(1), 37-45. Google Scholar

Fauzan, A. (2002). Applying Realistic Mathematics Education (RME) in teaching geometry in Indonesian primary schools. University Of Twente [Host]. Google Scholar

Fauzan, A., Slettenhaar, D., \& Plomp, T. (2002, April). Traditional mathematics education vs. realistic mathematics education: Hoping for changes. In Proceedings of the 3rd International Mathematics Education and Society Conference (pp. 1-4). Centre for Researh in Learning Mathematics Copenhagen, Denmark. Google Scholar

Harbour, K. E., Evanovich, L. L., Sweigart, C. A., \& Hughes, L. E. (2015). A brief review of effective teaching practices that maximize student engagement. Preventing School Failure, 59(1), 5-13. https://doi.org/10.1080/1045988X.2014.919136

Hayes, Hayes, Clarin, Hardian Hardian, and Tanjung Ayu Sumekar. "Pengaruh Brain Training Terhadap Tingkat Inteligensia Pada Kelompok Usia Dewasa Muda." Jurnal Kedokteran Diponegoro 6, no. 2 (2017): 402-416. Google Scholar

Hikmah, N. (2018). Pengaruh Model Pembelajaran Matematika Realistik Terhadap Kemampuan Pemecahan Masalah Matematika. JKPM (Jurnal Kajian Pendidikan Matematika), 4(1). https://doi.org/10.36456/buana_matematika.8.2:.1751.109-114

Hunt, A., Nipper, K., \& Nash, L. (2011). Virtual vs. Concrete Manipulatives in Mathematics Teacher Education: Is One Type More Effective than the Other?. Current Issues in Middle Level Education, 16(2), 1-6. Google Scholar

Kyriakides, L., Campbell, R. J., \& Christofidou, E. (2002). Generating criteria for measuring teacher effectiveness through a self-evaluation approach: A complementary way of measuring teacher effectiveness. School Effectiveness and School Improvement, 13(3), 291-325. https://doi.org/10.1076/sesi.13.3.291.3426

Mariam, M., Lidinillah, D. A. M., \& Hidayat, S. Desain Didaktis Luas Layanglayang untuk Pengembangan Berpikir Kreatif Siswa. PEDADIDAKTIKA: Jurnal Ilmiah Pendidikan Guru Sekolah Dasar, 4(2), 62-75. Google Scholar 
Marzuki, M., \& Khanifah, S. (2016). Pendidikan ideal perspektif Tagore dan Ki Hajar Dewantara dalam pembentukan karakter peserta didik. Jurnal Civics: Media Kajian Kewarganegaraan, 13(2), 172-181. https:// doi.org/10.21831/civics.v13i2.12740

Rokhmah, F., Yulina, Y., \& Siswantoro, S. (2018). Pengaruh Pendekatan RME terhadap Hasil Belajar Matematika Siswa SD. Jurnal Pedagogi, 7(3). Google Scholar

National Council of Teachers of Mathematics. (2000). Principles and Standards for School Mathematics. Dalam Reston. https://doi.org/10.1016/s07370806(98)80482-6

Panayiotou, A., Kyriakides, L., Creemers, B. P. M., McMahon, L., Vanlaar, G., Pfeifer, M., Rekalidou, G., \& Bren, M. (2014). Teacher behavior and student outcomes: Results of a European study. Educational Assessment, Evaluation and Accountability, 26(1), 73-93. https://doi.org/10.1007/s11092-013-9182-x

Paneque, O. M., \& Barbetta, P. M. (2006). A study of teacher efficacy of special education teachers of english language learners with disabilities. Bilingual Research Journal, 30(1), 171-193. https://doi.org/10.1080/15235882.2006.10162871

Rahman, A. A. (2018). Penerapan pendekatan Realistic Mathematic Education (RME) pada materi statistika untuk meningkatkan pemahaman konsep dan prestasi belajar siswa. GENTA MULIA: Jurnal Ilmiah Pendidikan, 8(2). Google Scholar

Antika, R., Ardila, R., \& Zanthy, L. S. (2019). Pendekatan Pendidikan Matematika Realistik Untuk Meningkatkan Kemampuan Penalaran Matematis Siswa SMP dan Kemampuan Percaya Diri. Journal on Education, 1(4), 605-611. Google Scholar

Scanlon, L. (2018). The Role of Research in Teachers' Work: Narratives of Classroom Action Research. Routledge. Google Scholar

Scheerens, J. (2015). Educational effectiveness and ineffectiveness: A critical review of the knowledge base. Dalam Educational Effectiveness and Ineffectiveness: A Critical Review of the Knowledge Base. https:// doi.org/10.1007/978-94-017-7459-8

Seidel, T., \& Shavelson, R. J. (2007). Teaching effectiveness research in the past decade: The role of theory and research design in disentangling metaanalysis results. Review of Educational Research, 77(4), 454-499. https://doi.org/10.3102/0034654307310317

Sitorus, J., \& Masrayati. (2016). Students' creative thinking process stages: Implementation of realistic mathematics education. Thinking Skills and Creativity, 22, 111-120. https:// doi.org/10.1016/j.tsc.2016.09.007

Skaalvik, E. M., \& Skaalvik, S. (2007). Dimensions of Teacher Self-Efficacy and Relations With Strain Factors, Perceived Collective Teacher Efficacy, and Teacher Burnout. Journal of Educational Psychology, 99(3), 611-625. https://doi.org/10.1037/0022-0663.99.3.611 
Sopyan, R., Dewi, M. K., Fauzan, G. A., \& Bernard, M. (2019). Penerapan Pendekatan Realistic Mathematic Education Untuk Meningkatkan Konsep Diri (Self Concept) Siswa SMP di Era Milenial. Journal on Education, 2(1), 45-42. Google Scholar

Stronge, J. H., Ward, T. J., \& Grant, L. W. (2011). What makes good teachers good?: A cross-case analysis of the connection between teacher effectiveness and student achievement. Journal of Teacher Education, 62(4), 339-355. https:// doi.org/10.1177/0022487111404241

Ningsih, S. (2014). Realistic Mathematics Education: Model Alternatif Pembelajaran Matematika Sekolah. Jurnal Pendidikan Matematika, 1(2), 7394. Google Scholar

Susilawati, S. (2019). Peningkatan Hasil Belajar Siswa Pada KD 3.6 Menjelaskan Dan Menemukan Jaring-Jaring Bangun Ruang Sederhana (Kubus Dan Balok) Melalui Penggunaan Media Benda Konkret Di Kelas V SD Negeri 5 Madurejo Tahun Pelajaran 2017/2018. Jurnal Hadratul Madaniyah, 6(2), 44-49. Google Scholar

Van de Grift, W. J. C. M., Van der Wal, M., \& Torenbeek, M. (2011). Ontwikkeling in de pedagogisch didactische vaardigheid van leraren in het basisonderwijs. Pedagogische Studiën, 88(6), 416-432. Google Scholar

Zakiy, M. A. Z., Syazali, M., \& Farida. (2018). Pengembangan Media Android dalam Pembelajaran Matematika. TRIPLE S:Jourals of Mathematics Education, 1(2), 87-96. Google Scholar

Copyright Holder :

(c) Sholikhah, O., Rasmita, R. (2020)

First Publication Right :

(C) Jurnal Iqra' : Kajian Ilmu Pendidikan

This article is under:

(이)(2) 